\title{
INFLUENCE OF TEST METHOD ON BIODEGRADATION OF BAMBOO-PLASTIC COMPOSITES BY FUNGI
}

\author{
E. Bari ${ }^{1, \diamond}$, A. Sistani ${ }^{2}$, H. R. Taghiyari ${ }^{3}$, J. J. Morrell ${ }^{4}$, J. Cappellazzi ${ }^{5}$
}

\begin{abstract}
The effects of differing ratios of bamboo/plastic polymers on resistance to fungal attack was assessed using two different decay test methods. Weight losses for non-treated southern pine and Carpinus betulus sapwood blocks indicated that the test conditions were suitable for aggressive decay by Gloeophyllum trabeum and Trametes versicolor. Mass losses on the bamboo/composites tended to be very low, regardless of the method employed. In general, moisture levels in the composites were extremely low although they were close to the point where fungal attack could occur when only the bamboo components were considered. The standard decay tests indicated that bamboo can be considered a suitable substitute for wood flour in wood-plastic composites.
\end{abstract}

Keywords: Bambusa arundinacea, biocomposites, Carpinus betulus, decay fungi, Gloeophyllum trabeum, Southern pine, Trametes versicolor, wood plastic composites.

\section{INTRODUCTION}

The production of composites composed of various plastic polymers and woody materials has created a tremendous opportunity to take advantage of the best properties of each material. For example, plastics can reduce moisture uptake and have exceptional flexural properties, while the woody materials can add stiffness and reduce over-all production costs (Klyosov 2007). When first produced, wood/plastic composites were assumed to be immune to fungal attack as it was presumed that the plastic would coat the wood, making it less likely to absorb moisture at levels that would support fungal growth (Mankowski and Morrell 2000, Morrell et al. 2006). However, it soon became apparent that moisture conditions were suitable for fungal attack (Schmidt 1993, Naghipour 1996, Mankowski and Morrell 2000, Schirp and Wolcott 2005, Chen et al. 2009, Kartal et al. 2013, Wei et al. 2013, Bari et al. 2015, Verhey et al. 2002) and efforts have since been made to improve resistance to fungal attack through the use of smaller particle sizes (Frank and Matuana 2008, Farhadnejad et al. 2012, Kartal et al. 2013, Bari et al. 2015, Ashori et al. 2015) as well as fungicidal additives such as zinc borate (Feng et al. 2014, 2016). At the same time, a variety of alternative cellulosic materials have been explored as composite components. One attractive material is bamboo, which grows rapidly and has excellent material properties (Liese 1985). Bamboo waste from processing for other markets such as flooring

\footnotetext{
${ }^{1}$ Department of Wood Science and Engineering, Technical Faculty of No. 2, Mazandaran Branch, Technical and Vocational University (TVU), Sari, Iran. bari_lenzites@yahoo.com \& e.bari@sanru.ac.ir

2Department of Wood and Paper Science, Sari Agriculture Science and Natural Resources University, Sari, Iran. sistani.asqar@ yahoo.com

${ }^{3}$ Wood Science and Technology Department, Faculty of Civil Engineering, Shahid Rajaee Teacher Training University (SRTTU), Tehran, Iran. htaghiyari@srttu.edu

${ }^{4}$ Department of Wood Science and Engineering, Oregon State University, Corvallis, OR, USA. jeff.morrell@oregonstate.edu ${ }^{5}$ Department of Wood Science and Engineering, Oregon State University, Corvallis, OR, USA jed.cappellazzi@oregonstate.edu "Corresponding author: e.bari@sanru.ac.ir

Received: 23.11.2016 Accepted: 14.06.2017
} 
might be an attractive material for this application, although this material is very susceptible to fungal damage (Schmidt et al. 2011). An important aspect of this development would be to ensure that the resulting products exhibited sufficient resistance to fungal attack. There are relatively few studies of bamboo/ plastic composite durability (Kartal et al. 2013, Feng et al. 2014, Feng et al. 2016). In this report, we describe evaluations of the resistance of composites made with bamboo and four different plastics. The objective of this study was to evaluate the durability of bamboo/plastic composites using two different decay evaluation methods.

\section{MATERIALS AND METHODS}

\section{Material preparation}

High density polyethylene (HDPE), low density polyethylene (LDPE), polyvinyl chloride (PVC), and polypropylene (PP) were purchased (Bandar-Emam Petrochemical Company, Iran) in granular form. Green stems of Bambusa arundinacea Willd. were air-dried under a sunshade for four weeks and then fragmented in a hammer mill. The whole bamboo stem, including epidermis and the nodes, was utilized. The resulting fragments were further ground to pass a 40 mesh screen then this mixture was passed through a 60 mesh screen. The flour was dried for 24 hours at $103 \pm 2^{\circ} \mathrm{C}$ and stored in sealed plastic bags to retard moisture absorption. Maleic anhydride grafted polypropylene (MAPP) was added as a compatibilizer, polyethylene wax was added as a lubricant, calcium carbonate was added as a filler, and Nano-clay or borax were added to as fire retardants. Boron also provides resistance to fungal and insect attack

\section{Sample preparation}

The dried bamboo flour and one of the four polymer powders were tested in one of three ratios while the additives were maintained at a constant level (Table 1). The plastic and additives were thoroughly blended before use while the bamboo was kept separate so that it could be added as late in the extrusion process as possible to reduce the effects of heat on the bamboo properties.

Table 1. Compositions of bamboo/plastic polymer mixtures evaluated for resistance to fungal attack and moisture uptake.

\begin{tabular}{|c|c|c|c|c|c|c|c|}
\hline & \multicolumn{7}{|c|}{ Composite materials formulation (\% wt/wt) } \\
\hline Treatment & $\begin{array}{c}\text { Bamboo } \\
\text { flour }\end{array}$ & Polymer & MAPP $^{*}$ & $\begin{array}{c}\text { Polyethylene } \\
\text { wax }\end{array}$ & $\begin{array}{c}\text { Calcium } \\
\text { carbonate }\end{array}$ & Borax & $\begin{array}{c}\text { Nano } \\
\text { clay }\end{array}$ \\
\hline A & 60 & 32 & 2 & 0,1 & 3,9 & 1 & 1 \\
\hline B & 50 & 42 & 2 & 0,1 & 3,9 & 1 & 1 \\
\hline C & 40 & 52 & 2 & 0,1 & 3,9 & 1 & 1 \\
\hline
\end{tabular}

\section{Extrusion}

Bamboo flour, plastic and additives were dry blended in a Reimelt Henschel FM L 30 KM 85 mixer until the mixture reached $120^{\circ} \mathrm{C}$. The dry blend was compounded to granulate by counter-rotating twin screw extrusion at a screw speed of $70 \mathrm{rpm}$ with a $2 \mathrm{~kg} / \mathrm{h}$ feed rate at $155^{\circ} \mathrm{C}, 160^{\circ} \mathrm{C}, 165^{\circ} \mathrm{C}, 170^{\circ} \mathrm{C}$ or $175^{\circ} \mathrm{C}$ from the hopper to the die for Zones, 1, 2, 3, 4 and 5, respectively (Collins, Germany). The plastic/additive mixtures were loaded into the feed hopper using a gravimetric metering device, while bamboo fiber was introduced to the barrel at the side feeder between zones 3 and 4 . Strands exited the circular extruder die with diameter of $3 \mathrm{~mm}$ and were pelletized. The pellets were then oven-dried at $80^{\circ} \mathrm{C}$ for $24 \mathrm{~h}$ and stored in a sealed plastic bag inside a desiccator prior to injection molding.

The pellets were then injection molded using a EM80 injection molder (Eimen Machine, Iran). 
The barrel was set at temperatures between $160^{\circ} \mathrm{C}-170^{\circ} \mathrm{C}$, injection pressure was 85 bar, cooling time was $55 \mathrm{~s}$ and mold temperature was $20^{\circ} \mathrm{C}$ with rotating speed of $45 \mathrm{rpm}$. The resulting bamboo/ plastic composite (BPC) had densities of 1,$07 ; 1,05 ; 1,26$ and $1,03 \mathrm{~g} / \mathrm{cm}^{3}$ for HDPE, LDPE, PVC and PP samples. The samples were cut to 30 by 10 by $5 \mathrm{~mm}$ thick specimens for durability assessments.

\section{Biological Tests}

The samples were exposed to two three different decay fungi using the European Standard EN-113 (EN 2004) and the American Wood Protection Standard E10 (AWPA 2012). The samples were oven dried and then subjected to 2,5 mrad of ionizing radiation from a cobalt 60 source. The samples were then evaluated for resistance to basidiomycete decay fungi according to procedures described in AWPA Standard E10 (AWPA 2012). Briefly, decay chambers were prepared by half filling $454 \mathrm{~mL}$ French squares with moist forest loam and placing a western hemlock (Tsuga heterophylla (Raf) Sarg.) (for the brown rot fungus) or alder (Alnus rubra Bong) (for the white rot fungus) feeder strip on the soil surface. The bottles were then loosely capped and autoclaved for 45 minutes at $121^{\circ} \mathrm{C}$. After cooling, the bottles were inoculated with $3 \mathrm{~mm}$ diameter malt agar disks cut from the actively growing edges of cultures of the test fungi. The fungi evaluated were Gloeophyllum trabeum (Pers.: Fr.) Murr. (isolate \# Madison 617) or Trametes versicolor (L.) Lloyd (isolate \# R-105). The first fungus produces brown rot, while the latter species causes white rot. The agar plugs were placed on the edges of the wood feeder strips, then the jars were loosely capped (to allow air exchange), and incubated until the feeder strip was thoroughly covered with fungal mycelium. The sterile test blocks were then placed on the surfaces of the feeder strips, the bottles were loosely capped and incubated at $28^{\circ} \mathrm{C}$ for 12 or 16 weeks for blocks exposed to brown or white rot fungi, respectively. Each treatment was evaluated on 6 bocks.

At the end of the incubation period, the blocks were removed, scraped clean of adhering mycelium, oven-dried $\left(103^{\circ} \mathrm{C}\right)$ and weighed. The difference between initial and final oven-dry weight was used as a measure of the decay resistance of each material.

The moisture absorbing ability of the materials was assessed by oven-drying and weighing 2 samples from each treatment and immersing them in distilled water at room temperature $\left(20-23^{\circ} \mathrm{C}\right)$ for three weeks and then weighing the samples again to determine moisture uptake.

A modification of European method EN-113 as described by Bravery (1978) was used to assess resistance to white and brown rot fungi. Samples of southern pine and Carpinus betulus sapwood of the same dimensions as those used for the AWPA test were oven-dried $\left(103^{\circ} \mathrm{C}\right)$ for 48 hours and weighed prior to being steamed sterilized for 20 minutes at $121^{\circ} \mathrm{C}$. The decay chambers were glass petri dishes containing 4,8\% malt extract agar that were inoculated with an agar plug cut from an actively growing culture of G. trabeum and T. versicolor (isolate 18 and 12, Technical Faculty of Sari No 2 (STF), Sari, Iran) or Chaetomium globosum Kunze (isolate P10, University of Hamburg). The cultures were incubated at $25^{\circ} \mathrm{C}$ until the fungus covered the agar, then the sterile samples were placed on glass rods on the surface. The plates were incubated for 120 days at $25^{\circ} \mathrm{C}$ and $60 \%$ relative humidity. At the end of the test, the blocks were removed, scraped clean of mycelium and weighed to determine final moisture content. The blocks were then oven dried and weighed to determine mass loss.

Resistance to soft rot attack was assessed using samples cut to the same dimension used for the E10 tests using either the EN-113 procedures with C. globosum as the test fungus or a non-sterile soil burial technique. The samples exposed in the non-sterile soil tests were oven-dried $\left(104^{\circ} \mathrm{C}\right)$ and weighed (nearest $0,01 \mathrm{~g}$ ). Glass jars $(450 \mathrm{ml})$ were half filled with a mixture of moist forest loam and compost, a $1 \mathrm{~cm}$ square of filter paper was placed on the surface, then the test wafers were added. The other half of the soil was added and a filter paper square was placed on top of the soil. The soil was moistened with distilled water to approximately $100 \%$ of its water holding capacity. The elevated moisture conditions were intended to create conditions suitable for development of soft rot fungi. The bottles were incubated at $32^{\circ} \mathrm{C}$ for 16 weeks, then the test samples were removed and weighed to determine moisture content prior to being oven-dried and weighed to determine mass loss over the exposure period. Non-treated southern pine samples were included as reference controls. Each variable was tested on six samples. 


\section{RESULTS AND DISCUSSION}

\section{Basidiomycete Exposures}

Weight losses of southern pine sapwood blocks in the AWPA-E10 test averaged 53,86 and 35,24\% for blocks exposed to G. trabeum and T. versicolor, respectively (Table 2). While the white rot weight loss was a bit lower than the AWPA-E10 test recommends, this fungus tends to cause much lower weight losses on softwoods (Zabel and Morrell 1992). The results indicate that conditions were suitable for aggressive fungal attack. Weight losses for the hornbeam blocks in the EN-113 test were 20,0\% and $21,4 \%$ for the G. trabeum and T. versicolor, respectively. The weight losses were somewhat lower than those found for the E10 test, but still indicated that the fungi were capable of substantial wood degradation. Weight losses for the various bamboo/plastic composites were far below those found with the pine sapwood or hornbeam, ranging from 0,52 to $3,87 \%$ for the various treatments in the E10 test and 1,34 to $3,22 \%$ in the EN-113 test.

Table 2. Mass losses of bamboo plastic composites composed of different plastic polymers and non-treated southern pine and Carpinus betulus samples exposed to white and brown rot fungi in EN113 and AWPA-E10 decay tests.

\begin{tabular}{|c|c|c|c|c|c|c|c|}
\hline \multirow{2}{*}{ Plastic } & \multirow{2}{*}{$\begin{array}{l}\text { Bamboo/ } \\
\text { Plastic ratio }\end{array}$} & \multicolumn{2}{|c|}{$\begin{array}{c}\text { E10 } \\
\text { Mass Loss }(\%)^{\mathrm{a}}\end{array}$} & \multicolumn{2}{|c|}{$\begin{array}{c}\text { EN-113 } \\
\text { Mass Loss (\%) }\end{array}$} & \multicolumn{2}{|c|}{$\begin{array}{l}\text { EN-113 } \\
\text { MC (\%) }\end{array}$} \\
\hline & & $\begin{array}{c}G . \\
\text { trabeum }\end{array}$ & $\begin{array}{c}T . \\
\text { versicolor }\end{array}$ & $\begin{array}{c}\text { G. } \\
\text { trabeum }\end{array}$ & $\begin{array}{c}T . \\
\text { versicolor }\end{array}$ & $\begin{array}{c}G . \\
\text { trabeum }\end{array}$ & $\begin{array}{c}T . \\
\text { versicolor }\end{array}$ \\
\hline \multirow{3}{*}{$\begin{array}{l}\text { High density } \\
\text { polyethylene }\end{array}$} & $60 / 32$ & $\begin{array}{c}2,65 \\
(0,92)\end{array}$ & $\begin{array}{c}1,44 \\
(0,98)\end{array}$ & $\begin{array}{c}2,86 \\
(1,06)\end{array}$ & $\begin{array}{c}2,57 \\
(1,00)\end{array}$ & $\begin{array}{l}16,79 \\
(2,48)\end{array}$ & $\begin{array}{c}8,01 \\
(4,80)\end{array}$ \\
\hline & $50 / 42$ & $\begin{array}{c}0,56 \\
(0,45)\end{array}$ & $\begin{array}{c}0,76 \\
(0,36)\end{array}$ & $\begin{array}{c}2,08 \\
(1,95)\end{array}$ & $\begin{array}{c}2,17 \\
(0,21)\end{array}$ & $\begin{array}{l}14,37 \\
(7,39)\end{array}$ & $\begin{array}{c}8,47 \\
(5,40)\end{array}$ \\
\hline & $40 / 52$ & $\begin{array}{c}3,15 \\
(1,66)\end{array}$ & $\begin{array}{c}2,26 \\
(1,31)\end{array}$ & $\begin{array}{c}3,18 \\
(1,32)\end{array}$ & $\begin{array}{c}2,16 \\
(0,38)\end{array}$ & $\begin{array}{l}20,54 \\
(9,21)\end{array}$ & $\begin{array}{l}10,16 \\
(0,72)\end{array}$ \\
\hline \multirow{3}{*}{$\begin{array}{l}\text { Low density } \\
\text { polyethylene }\end{array}$} & $60 / 32$ & $\begin{array}{c}0,52 \\
(0,55)\end{array}$ & $\begin{array}{c}0,56 \\
(0,27)\end{array}$ & $\begin{array}{c}3,22 \\
(1,70)\end{array}$ & $\begin{array}{c}2,60 \\
(1,02)\end{array}$ & $\begin{array}{l}14,36 \\
(8,83)\end{array}$ & $\begin{array}{l}12,57 \\
(4,10)\end{array}$ \\
\hline & $50 / 42$ & $\begin{array}{c}0,97 \\
(1,48)\end{array}$ & $\begin{array}{c}1,27 \\
(0,65)\end{array}$ & $\begin{array}{c}1,34 \\
(1,04)\end{array}$ & $\begin{array}{c}1,95 \\
(0,04)\end{array}$ & $\begin{array}{l}11,51 \\
(6,52)\end{array}$ & $\begin{array}{l}19,71 \\
(9,61)\end{array}$ \\
\hline & $40 / 52$ & $\begin{array}{c}3,03 \\
(1,38)\end{array}$ & $\begin{array}{c}1,09 \\
(0,76)\end{array}$ & $\begin{array}{c}2,64 \\
(0,89)\end{array}$ & $\begin{array}{c}2,23 \\
(0,77)\end{array}$ & $\begin{array}{l}13,49 \\
(6,27)\end{array}$ & $\begin{array}{l}16,01 \\
(7,34)\end{array}$ \\
\hline \multirow{3}{*}{ Polypropylene } & $60 / 32$ & $\begin{array}{c}1,91 \\
(1,20)\end{array}$ & $\begin{array}{c}1,11 \\
(0,65)\end{array}$ & $\begin{array}{c}1,96 \\
(0,03)\end{array}$ & $\begin{array}{c}1,55 \\
(1,20)\end{array}$ & $\begin{array}{l}10,04 \\
(2,09)\end{array}$ & $\begin{array}{l}10,55 \\
(0,59)\end{array}$ \\
\hline & $50 / 42$ & $\begin{array}{c}3,87 \\
(0,74) \\
\end{array}$ & $\begin{array}{c}1,93 \\
(0,79) \\
\end{array}$ & $\begin{array}{c}2,01 \\
(0,16)\end{array}$ & $\begin{array}{c}2,06 \\
(0,11) \\
\end{array}$ & $\begin{array}{l}10,49 \\
(0,49) \\
\end{array}$ & $\begin{array}{l}13,18 \\
(5,60)\end{array}$ \\
\hline & $40 / 52$ & $\begin{array}{c}0,68 \\
(0,59)\end{array}$ & $\begin{array}{c}0,85 \\
(0,38)\end{array}$ & $\begin{array}{c}2,00 \\
(0,06)\end{array}$ & $\begin{array}{c}1,41 \\
(1,10)\end{array}$ & $\begin{array}{c}9,69 \\
(1,18)\end{array}$ & $\begin{array}{l}11,38 \\
(2,46)\end{array}$ \\
\hline \multirow{3}{*}{ Polyvinyl chloride } & $60 / 32$ & $\begin{array}{c}2,31 \\
(0,76) \\
\end{array}$ & $\begin{array}{c}1,94 \\
(1,53)\end{array}$ & $\begin{array}{c}1,89 \\
(0,09) \\
\end{array}$ & $\begin{array}{c}2,13 \\
(0,34)\end{array}$ & $\begin{array}{l}20,40 \\
(0,62) \\
\end{array}$ & $\begin{array}{l}15,35 \\
(0,54) \\
\end{array}$ \\
\hline & $50 / 42$ & $\begin{array}{c}3,71 \\
(1,76)\end{array}$ & $\begin{array}{c}0,81 \\
(0,67)\end{array}$ & $\begin{array}{c}2,82 \\
(9,02)\end{array}$ & $\begin{array}{l}1,35 \\
(1,05)\end{array}$ & $\begin{array}{l}20,46 \\
(9,47)\end{array}$ & $\begin{array}{l}13,45 \\
(0,91)\end{array}$ \\
\hline & $40 / 52$ & $\begin{array}{c}3,48 \\
(1,08)\end{array}$ & $\begin{array}{c}1,18 \\
(0,44)\end{array}$ & $\begin{array}{c}1,91 \\
(0,37)\end{array}$ & $\begin{array}{c}1,84 \\
(0,32)\end{array}$ & $\begin{array}{l}25,25 \\
(1,73)\end{array}$ & $\begin{array}{l}14,32 \\
(1,14)\end{array}$ \\
\hline $\begin{array}{l}\text { Southern pine } \\
\text { sapwood/Carpinus } \\
\text { betulus sapwood }\end{array}$ & - & $\begin{array}{l}53,86 \\
(7,30)\end{array}$ & $\begin{array}{l}35,24 \\
(6,23)\end{array}$ & $\begin{array}{l}20,04 \\
(0,10)\end{array}$ & $\begin{array}{l}21,42 \\
(1,29)\end{array}$ & $\begin{array}{l}46,70 \\
(0,30)\end{array}$ & $\begin{array}{l}56,40 \\
(1,66)\end{array}$ \\
\hline
\end{tabular}

aValues represent means of 12 replicates per treatment for all bamboo/plastic composites and 6 replicates for the non-treated southern pine and $C$. betulus controls. Values in parentheses represent one standard deviation.

Samples prepared using polyvinyl chloride tended to have consistently higher weight losses than materials prepared using the other polymers in the E10 test, although this polymer was not associated with the highest mass loss. The results were not as clear when the EN-113 test was employed on the same materials. The use of different levels of bamboo in the mixtures should be expected to alter 
susceptibility to fungal attack. In general, increasing amounts of plastic should have resulted in more complete encapsulation of the bamboo particles which should slow moisture uptake and limit the risk of fungal attack. However, some of the higher mass losses for the HPDE and LPDE samples occurred with the lowest amounts of bamboo for materials exposed using both test methods. It is unclear why this occurred. In general; however, the ability of the test fungi to attack and degrade the bamboo/ plastic mixtures was extremely limited. One aspect of the composite that likely affects susceptibility to fungal attack is moisture resistance (Rowell 2007, Kim et al. 2008, Kim et al. 2009, Defoirdt et al. 2010). Moisture levels in samples exposed in the EN-113 test ranged from 8,0 to $19,7 \%$ depending on the material. The HDPE samples had the lowest moisture contents, while the LDPE and PVC samples attained the highest moisture levels. Immersing samples for 3 weeks in distilled water showed that samples containing polyvinyl chloride sorbed the most moisture, followed by the high density polyethylene and finally polypropylene (Table 3 ). The PVC results appear related to the higher mass losses although the relationship between mass loss and moisture uptake was more tenuous with the other polymers. This behavior of PVC was seen in a former study (Muller et al. 2013). Low moisture levels are often a problem in laboratory decay tests of wood/plastic composites and also appear to be a factor with bamboo. It is important, however, to note that moisture levels are actually much higher and, in many cases, closer to the point where fungal attack can begin if only the bamboo component is considered. This is particularly true for the PVC containing systems. Kartal et al. (2013) reported much lower mass losses in pine/polyethylene composites with wood particle content (30-60) when compared to composite samples with wood content (50-70). Verhey et al. (2002) observed more mass loss in wood fiber/thermoplastic composites with higher wood content.

Table 3. Moisture contents of bamboo/plastic composites after 3 weeks of immersion in distilled water at $20-23^{\circ} \mathrm{C}$.

\begin{tabular}{|l|c|c|}
\hline Plastic & Bamboo/Plastic ratio & Moisture Content (\%) \\
\hline \multirow{3}{*}{ High Density Polyethylene } & $60 / 32$ & 11,74 \\
\cline { 2 - 3 } & $50 / 42$ & 10,14 \\
\cline { 2 - 3 } & $40 / 52$ & 14,60 \\
\hline \multirow{3}{*}{ Low Density Polyethylene } & $60 / 32$ & 6,63 \\
\cline { 2 - 3 } & $50 / 42$ & 5,56 \\
\cline { 2 - 3 } & $40 / 52$ & 7,06 \\
\hline \multirow{3}{*}{ Polypropylene } & $60 / 32$ & 7,34 \\
\cline { 2 - 3 } & $50 / 42$ & 10,93 \\
\cline { 2 - 3 } & $40 / 52$ & 4,90 \\
\hline \multirow{3}{*}{ Polyvinyl chloride } & $60 / 32$ & 18,58 \\
\cline { 2 - 3 } & $50 / 42$ & 19,64 \\
\cline { 2 - 3 } & $40 / 52$ & 24,58 \\
\hline
\end{tabular}

\section{Soft Rot Test}

Mass losses of southern pine sapwood blocks in the soft rot burial test were much lower than those found with the AWPA-E10 test, reflecting the tendency for soft rot fungi to attack more slowly and to be less capable of damaging coniferous woods (Table 4). Mass losses for the pine controls averaged $14,08 \%$ while the final moisture content was $93 \%$. Mass losses for the various bamboo plastic composites were much lower than those for the pine, but higher than those found with the soil block test. The highest mass losses were found with bamboo/polyvinylchloride polymers. Interestingly, mass losses increased with decreasing bamboo content for this composite. However, final moisture content also followed the same trend. It is unclear whether the lower bamboo content created mixing problems, but the results were contrary to those expected. As noted, lower bamboo content should improve particle encapsulation that should reduce both moisture uptake and susceptibility to fungal 
attack. Moisture contents for composites containing either high or low density polyethylene tended to be similar regardless of bamboo content, while those with polypropylene were inconsistent, with the highest moisture content occurring with the middle bamboo content.

Table 4. Mass losses and final moisture contents of bamboo/plastic polymers exposed for 16 weeks in a soft rot burial test.

\begin{tabular}{|c|c|c|c|c|c|}
\hline \multirow[t]{2}{*}{ Plastic } & \multirow[t]{2}{*}{$\begin{array}{c}\text { Bamboo/Plastic } \\
\text { Ratio }\end{array}$} & \multicolumn{2}{|c|}{$\begin{array}{l}\text { Non sterile soil } \\
\text { Mass Loss (\%) }\end{array}$} & \multicolumn{2}{|c|}{ C. globosum (EN-113) } \\
\hline & & & $\begin{array}{c}\text { Final MC } \\
(\%)\end{array}$ & $\begin{array}{l}\text { Mass Loss } \\
(\%)\end{array}$ & $\begin{array}{c}\text { Final MC } \\
(\%)\end{array}$ \\
\hline \multirow{3}{*}{ High density polyethylene } & $60 / 32$ & $4,13(2,42)$ & 11,8 & $1,42(1,11)$ & 6,1 \\
\hline & $50 / 42$ & $0,82(1,16)$ & 10,1 & $2,12(0,10)$ & 7,2 \\
\hline & $40 / 52$ & $5,57(1,83)$ & 14,7 & $1,87(1,29)$ & 18,4 \\
\hline \multirow{3}{*}{ Low density polyethylene } & $60 / 32$ & $1,87(1,71)$ & 6,7 & $2,05(0,15)$ & 17,1 \\
\hline & $50 / 42$ & $0,73(0,80)$ & 5,4 & $2,07(0,12)$ & 11,4 \\
\hline & $40 / 52$ & $2,29(1,63)$ & 7,1 & $1,71(0,06)$ & 21,5 \\
\hline \multirow{3}{*}{ Polypropylene } & $60 / 32$ & $3,30(1,08)$ & 7,4 & $2,00(0,10)$ & 11,1 \\
\hline & $50 / 42$ & $5,13(0,61)$ & 10,9 & $2,69(1,29)$ & 8,0 \\
\hline & $40 / 52$ & $1,44(1,18)$ & 4,9 & $1,98(0,10)$ & 12,4 \\
\hline \multirow{3}{*}{ Polyvinyl chloride } & $60 / 32$ & $5,72(0,55)$ & 18,1 & $3,53(2,90)$ & 14,8 \\
\hline & $50 / 42$ & $6,87(0,51)$ & 19,9 & $2,49(2,72)$ & 15,8 \\
\hline & $40 / 52$ & $8,92(1,10)$ & 24,6 & $2,81(1,04)$ & 22,0 \\
\hline Southern pine & - & $14,08(1,55)$ & 93,2 & - & - \\
\hline Carpinus betulus & - & - & - & $18,57(0,10)$ & 37,1 \\
\hline
\end{tabular}

Values represent means of 12 samples for each bamboo/plastic ratio and 6 replicates for the southern pine control in the non-sterile soil and 3 replicates for the C. globosum test. Figures in parentheses represent one standard deviation.

Mass losses in samples exposed to C. globosum in an EN-113 test ranged from 1,42 to 3,53\% while the hornbeam control blocks had a weight loss of $18,6 \%$ (Table 4). Moisture contents tended to be higher in samples exposed in the EN-113 test, compared with the soil burial procedure, but the higher moisture content did not translate into higher mass loss.

While the soft rot results were again lower than those found with solid wood, the soil exposure tests suggest a higher sensitivity to soft rot attack (Table 4). This may reflect the development of higher moisture levels that would be more conducive to fungal attack than those produced in the AWPA-E10 soil block test. It is also important to consider that the moisture contents reported were for the full composite. Moisture sorption by the plastic component should be extremely limited; the majority of the moisture would be in the bamboo particles and would be concentrated near the sample surface. Thus, conditions in the bamboo particles in the polyvinyl composites would approach 30,$2 ; 39,5$ and $61,5 \%$ moisture content for the 60,50 and $40 \%$ bamboo respectively, if just the bamboo is considered. These moisture levels would be suitable for more aggressive fungal attack in the soil exposure. It is unclear why the elevated moisture levels observed with C. globosum in the EN-113 test did not also result in higher mass losses, but this might reflect the ability of the fungus to function in this test environment. This standard was developed for basidiomycetes and the conditions may be less suitable for this ascomycete.

\section{CONCLUSIONS}

Bamboo/plastic composites containing $1 \%$ borax were generally far less susceptible to fungal attack than non-treated southern pine controls. Samples containing polyvinyl chloride tended to reach higher moisture levels and experience more fungal mass loss than sample containing high or low density polyethylene or polypropylene. While the weight losses were generally low, they did suggest that the samples were more susceptible to soft rot attack than conventional white and brown rot fungi. 
Neither of the standard decay tests produced an environment that encouraged large mass losses on the bamboo/plastic materials, regardless of plastic polymer type. The results suggest the need for further modifications of laboratory decay test methodologies to more aggressively test these composite materials.

\section{ACKNOWLEDGEMENTS}

The authors appreciate the efforts of Engineer Mehdi Khoshkar, Technical Faculty of Sari No 2 (STF) for preparation of bamboo-plastic samples. This study was financed by the Department of Wood Science and Engineering, Technical Faculty of Sari No 2 (STF), Iran.

\section{REFERENCES}

American Wood Protection Association. AWPA. 2012. Standard E10, AWPA Book of standards, Birmingham, Alabama.

Ashori, A.; Behzadi Shahrebabak, A.; Madhoushi, M. 2015. Effects of nanoclay and coupling agent on fungal degradation and water absorption of sanding dust/high density polyethylene composites. Journal of Composite Materials 49(9): 1107-1114.

Bari, E.; Taghiyari, H.R.; Schmidt, O.; Ghorbani, A.; Aghababaei, H. 2015. Effects of nano-clay on biological resistance of wood-plastic composite against five wood-deteriorating fungi. Maderas-Cienc Tecnol 17(1): 205-212.

Bravery, A.F. 1978. A miniaturised wood-block test for the rapid evaluation of wood preservative fungicides. Document No. IRG/WP 2113. International Research Group on Wood Protection, Stockholm.

European Committee for Standardization. EN. 2004. Wood preservatives - Test method for determining the protective effectiveness against wood destroying basidiomycetes. Determination of toxic values. EN-113.

Chen, H.Y.; Miao, M.H.; Ding, X. 2009. Influence of moisture absorption on the interfacial strength of bamboo/vinyl ester composites. Compos. A: Applied Sci Manuf 40: 2013-2019.

Defoirdt, N.; Gardin, S.; Van den Bulcke, J.; Van Acker, J. 2010. Moisture dynamics of WPC and the impact on fungal testing. Int Biodeterior Biodegrad 64(1): 65-72.

Farhadinejad, Z.; Ehsani, M.; Khosravian, B.; Ebrahimi, G. 2012. Study of thermal properties of wood plastic composite reinforced with cellulose micro fibril and nano inorganic fiber filler. Eur $J$ Wood Prod 70(6): 823-828.

Feng, J.; Shi, Q.; Chen, Y.; Huang, X. 2014. Mold resistance and water absorption of Wood/ HDPE and Bamboo/HDPE composites. Journal of Applied Sciences 14: 776-783.

Feng, J.; Zhang, H.; He, H.; Huang, X.; Shi, Q. 2016. Effects of fungicides on mold resistance and mechanical properties of wood and bambooflour/high-density polyethylene composites. BioResource 11(2): 4069-4085.

Frank, M.; Matuana, L.M. 2008. Nanoclay reinforced HDPE as a matrix for wood-plastic composites. Composites Science and Technology 68(9): 2073-2077.

Kartal, S.N.; Aysal, S.; Terzi, E.; Yilgor, N.; Yoshimura, T.; Tsunoda, K. 2013. Wood and Bamboo-PP composites: Fungal and termite resistance, water absorption and FT-IR analysis. BioResource 8: 1222-1244.

Kim, J.W.; Harper, D.P.; Taylor, A.M. 2008. Effect of wood species on water sorption and durability of wood-plastic composites. Wood Fiber Sci 40(4): 519-531. 
Kim, J.W.; Harper, D.P.; Taylor, A.M. 2009. Effect of extractives on water sorption and durability of wood-plastic composites. Wood Fiber Sci 41(3): 279-290.

Klyosov, A.A. 2007. Wood-plastic composites. John Wiley and Sons, Inc.

Liese, W. 1985. Bamboos - biology, silvics, properties, utilization. Schriftenreihe Gesellschaft für Technische Zusammenarbeit, Eschborn, 180, p.132.

Mankowski, M.; Morrell, J.J. 2000. Patterns of fungal attack in wood-plastic composites following exposure in a soil block test. Wood Fiber Sci 32(3): 340-345.

Morrell, J.J.; Stark, N.M.; Pendleton, D.E.; McDonald, A.G. 2006. Durability of wood-plastic composites. Wood Design Focus 16(3): 7-10.

Muller, M.; Gellerich, A.; Militz, H.; Krause, A. 2013. Resistance of modified polyvinyl chloride/ wood flour composites to basidiomycetes. Eur J Wood Prod 71: 199-204.

Naghipour, B. 1996. Effects of extreme environmental conditions and fungal exposure on the properties of wood-plastic composites. M.S. Thesis, Faculty of Forestry, University of Toronto, Toronto, Ontario, Canada. p. 79.

Rowell, R.M. 2007. Challenges in biomass-thermoplastic composites. J Polym Environ 15(4): 229-235.

Schirp, A.; Wolcott, M.P. 2005. Influence of fungal decay and moisture absorption on mechanical properties of extruded wood-plastic composites. Wood Fiber Sci 37: 643-652.

Schmidt, E. 1993. Decay testing and moisture changes for a plastic-wood composite. Proc Am Wood-Preserv Assoc 89: 108-109.

Schmidt, O.; Wei, D.S.; Liese, W.; Wollenberg, E. 2011. Fungal degradation of bamboo samples. Holzforschung 65: 883-888

Wei, L.; McDonald, A.G.; Freitag, C.; Morrell, J.J. 2013. Effects of wood fiber esterification on properties, weatherability and biodurability of wood plastic composites. Polymer Degradation and Stability 98(7): 1348-1361.

Verhey, S.A.; Laks, P.E.; Richter, D.L. 2002. Laboratory decay resistance of wood fiber/ thermoplastic composites. Sixth International Conference on Wood Fiber Plastic Composites, the Forest Products Society, Madison, Wisconsin. pp. 79-86

Zabel, R.A.; Morrell, J.J. 1992. Wood microbiology: decay and its prevention. Academic Press, New York. 